\title{
Can Japan Meet Its 2030 Nuclear Power Target?
}

\author{
Romain Zissler and JefFrey S. CROSS* \\ Tokyo Institute of Technology, Japan
}

\begin{abstract}
The 2010s marked a turning point in Japan's nuclear power's industry. In fiscal year 2010, nuclear power electricity generation stood at 288.2 terawatt-hours. In 2011, the Great East Japan Earthquake triggered a tsunami and a major accident at the Fukushima Daiichi nuclear power plant. In 2014, nuclear power electricity generation eventually bottomed out at 0 terawatt-hour due to the temporary closures of all the reactors. In 2015, Japan's Government advanced its landmark Long-term Energy Supply and Demand Outlook targeting nuclear power electricity generation to reach 216.8-231.7 terawatt-hours in fiscal year 2030 - granting a key role to this technology in terms of low carbon and stable domestic electricity supply. However, confronted to the challenges of meeting more stringent safety standards, many nuclear reactors have been permanently shut down, and future restarts are unclear. Given this scenario, this paper demonstrates that meeting Japan's nuclear power 2030 target is unlikely. Furthermore, Japan has recently set a net zero greenhouse gas emission goal by 2050 making decarbonization of its electrical power generation, a future need. Although improvements in energy efficiency and greater deployment of renewable energies are two potential ways to overcome the shortfall, this paper discusses how proposed international electrical interconnections may serve as efficient and economical alternatives to meet nuclear power's expected shortfall that also addresses climate change mitigation, electricity security strengthening, and resiliency.
\end{abstract}

Keywords: Japan, nuclear power, projections, international electrical interconnections

\section{INTRODUCTION}

In response to the oil shocks of the 1970s, nuclear power became a significant source of electricity in fossil-fuel poor Japan from the 1980s. According to statistics from the International Energy Agency (IEA) [1], (gross) electricity generation from nuclear power reached its peak in Japan at the turn of the century, fiscal years (FY, in Japan fiscal years start on April 1st and end on March 31st) 1996-2001, when on an annual basis it consistently generated more than 300 terawatt-hours (TWh). Then, until FY 2010, it oscillated between about 250 TWh and 300 TWh.

In March 2011, the Great East Japan Earthquake that triggered a tsunami and a major accident at the Fukushima Daiichi nuclear power plant completely disrupted the Japanese nuclear industry. At this time, according to the Japan Atomic Industrial Forum [2], the Japanese nuclear power fleet

*Corresponding author: cross.j.aa@m.titech.ac.jp

Received: 2 Aug 2021 Accepted: 30 Sep 2021 Published: 7 Oct 2021

Journal of Asian Energy Studies (2021), Vol 5, 22-41, doi:10.24112/jaes.050003 
included 55 operational reactors. This accident led to the permanent shutdowns of all six nuclear reactors at the Fukushima nuclear power plant (FY 2012-2013) and the temporary closures of all reactors across the country for safety inspections. As a result, electricity generation from nuclear power eventually bottomed out at 0 TWh in FY 2014.

In July 2015, the Japanese Ministry of Economy, Trade and Industry (METI) advanced its landmark Long-term Energy Supply and Demand Outlook [3] targeting electricity generation from nuclear power to reach between 216.8 and 231.7 TWh in FY 2030, an objective better known as the $20-22 \%$ target. This ambitious goal grants a key role to nuclear power recognized as a solution for both low carbon electricity generation and stable supply of power.

Since FY 2015, however, confronted to the economic and technical challenges of meeting more stringent safety standards, Japanese electric power companies have permanently shut down 16 nuclear reactors. In total, since the Fukushima accident 22 nuclear reactors have thus been permanently shut down, a fleet reduction of $40 \%$. In addition, of the 33 remaining reactors, only 9 had restarted commercial operation as of mid-2021. In FY 2019, electricity generation from nuclear power amounted to just 63.8 TWh - less than 30\% of its FY 2030 target. Fig. 1 summarizes the evolution of electricity generation from nuclear power in Japan from FY 2010 to FY 2019, and the targeted range for FY 2030.

This paper aims to analyze the likelihood of Japan meeting its 2030 nuclear power target. The rest of the paper proceeds as follows. Section 2 reviews the relevant literature. Section 3 focuses on our methodology describing in details the current status of nuclear reactors in Japan as well as the scenarios and assumptions developed to assess the feasibility of meeting Japan's nuclear power FY 2030 target. Section 4 shows and discusses our estimation results. It is followed by Section 5 developing further considerations including the role those international electrical interconnections could play as innovative alternatives to the expected nuclear power shortfall in FY 2030 or beyond. Finally, Section 6 concludes our analysis by summarizing findings.

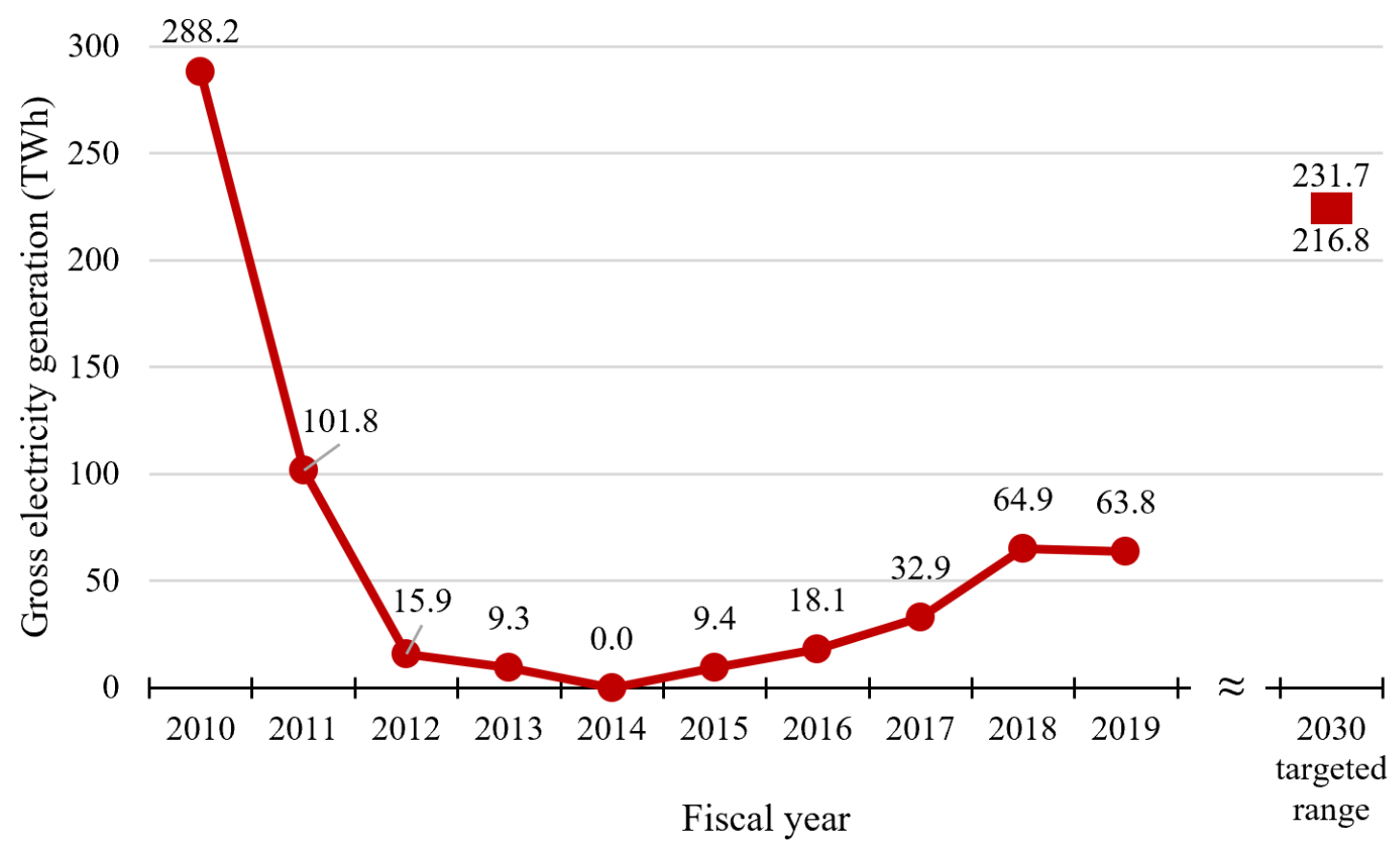

Figure 1: Gross electricity generation from nuclear power in Japan FY 2010-2019 and FY 2030 targeted range [1,3] 


\section{Literature ReVieW}

A number of peer reviewed research papers and energy outlook from think tanks that focus on Japan's electricity generation projections have been published in the period 2016-2020, out of which four have been selected and are presented briefly in the following paragraph. To address the uncertainties related to the future level of electricity generation from nuclear power, the authors often rely on rather simple assumptions.

For instance, Kuriyama et al. [4] make four assumptions regarding the future share of nuclear power in total electricity generation in FY 2030, which could be $0 \%, 15 \%, 20 \%$, and $25 \%$, with little evidence supporting these numbers. Yamazaki and Takeda [5] consider three scenarios: The IEA's World Energy Outlook "New Policies Scenario" (predecessor of the "Stated Policies Scenario," reflecting announced policies and targets), a 40-year operational time limit of nuclear power plants, and no restart of nuclear power plants, excluding the possibility of a 60-year operational lifetime as actually granted to four reactors (as of July 2021) - and without explicitly disclosing information about assumed nuclear reactors capacity factors. Wakiyama and Kuriyama [6], provide the most relevant methodology by setting a 40 -year operational time limit of nuclear power plants (same as the central scenario of [5]) and discussing the impacts of various capacity factors. Yet, they fell short at presenting an exhaustive analysis, and at covering the possibility of a 60-year operational lifetime. Moreover, none of these studies indicates reactor specific current operation status details. Finally, in its latest Outlook, The Institute of Energy Economics, Japan [7] makes two projections for electricity generation from nuclear power in Japan in 2030 without clearly specifying assumptions other than a mere reference to national targets for its "Advanced Technologies Scenario."

In the past, there have been many examples of forecasts failing to represent electricity generating technologies trajectories. For example, Carrington and Stephenson [8] examined solar photovoltaic (PV) projections in 26 global energy scenarios, including the above-mentioned IEA's World Energy Outlook, and found that they all failed to account fully for technology developments. Furthermore, they warned that quality poor projections affect energy policy planning and financially impacts investors.

In the building of nuclear power plants, delays in their construction and costs over runs are relatively common [9]. As a result, there are a number of examples showing nuclear power expected generation having empirically underperformed against theoretical expectations or governmental targets. For instance, in November 2015 - a few months after METI adopted its Long-term Energy Supply and Demand Outlook, the IEA's World Energy Outlook [10] predicted that - across all its scenarios - 175 TWh of gross electricity would be generated from nuclear power in Japan in FY 2020. According to preliminary data by the IEA released in July 2021 [11], only 36 TWh of net electricity was generated from nuclear in Japan in FY 2020 - roughly almost five times less (i.e., it is not possible to directly accurately compare "gross" and "net," but the difference should not be very significant). Another recent example of failed nuclear power projection is in China, which targeted 58 gigawatts of nuclear power installed capacity by the end of 2020, but only managed to reach 51 gigawatts [12].

Regarding energy mix modeling, Fazendeiro and Simoes [13] propose two possible ways to improve energy system projections: more sophisticated modeling to deal with disruptive events or very fast transitions (especially relevant in the case of new technologies), and/or a more thorough work on the assumptions based on empirical observations and realistic expectations. In this paper, nuclear power being a well-established technology, the methodology implemented is not particularly sophisticated, but appropriate and most of the efforts are concentrated on the initial assumptions related to the expected output. Furthermore, policymakers in the planning stage of policy may be more reactive and flexible to reconciliate energy progress, projections and goals. 
For example, India facing challenges to expand nuclear power in the long term, rebalanced its ambitions and efforts in favor of another low carbon technology solar [14].

Having identified areas of improvement for nuclear power projections in Japan in previously published research papers, aware of the possibilities of failed projections and their risks, and solicitous about proposing solutions to the current situation, this paper aims at providing more comprehensive and credible projections for the quantity of electricity to be generated from nuclear power in Japan in FY 2030. This objective is to be reached by clearly providing all up-to-date relevant information and assumptions. The results presented here are replicable thanks to the content made available in these pages which is based on publicly available data and analyses. This is a necessary enterprise to support the assertion that it is unlikely to meet the country's nuclear FY 2030 policy target.

In addition, this paper also proposes alternatives to meet nuclear power's expected contributions; climate change mitigation and security of electricity power supply strengthening. Although one may think that simply building more solar based power plants in Japan could replace unmet nuclear power projections this does not consider priority electricity dispatch rules [15], which has resulted in locally curtailed solar energy which will be explained later. In particular, the role of possible international electrical interconnections is innovatively discussed. These interconnections are physical infrastructures enabling to transport electricity across international borders. This means Japan which is currently an isolated electrical island could - if interconnected with one or more of its neighboring countries via submarine cables - export or import of electricity depending on power systems' needs. The European Union [16] is the world's best example of long-term policy planning for international electrical interconnections. In Europe in 2018, the latest year for which data is available, there are well over 400 cross-border transmission lines [17] through which $454 \mathrm{TWh}$, or almost $11 \%$ of the continent's total electricity production, were traded [18]. Another good example is the four times smaller power system of the Association of Southeast Asian Nations (ASEAN) [19] where active cross-border electricity trade also takes place (32-33 TWh in 2018) [20], especially in the Mekong River basin with Laos being the main net exporter of the region [21] and Thailand the main net importer [22]. Historically, the factors for developing these initiatives were economics (i.e., trading the most cost competitive electricity) and security of supply (i.e., taking advantage of power system complementarities). The climate change mitigation factor has been advanced more recently. Decarbonization is partly based on electricity generation from solar and wind power which outputs are variable resulting in periods of high or low supply, regardless of demand. International electrical interconnections allowing to export or import electricity enable adjustments for excess or shortfall of electricity generation from variable renewable energies. In this framework, the announcement by Japan's new prime minister Yoshihide Suga in October 2020 that the country now targets carbon neutrality by 2050 [23] makes the idea of international electrical interconnections even more relevant. Beyond these benefits, in the case of Japan, international electrical interconnections could also contribute to the country's power system resiliency issue due frequent local natural disasters (e.g., earthquakes, seasonal flooding, tsunamis, typhoons, volcanic eruptions...).

\section{Methodology}

Projections are characterized by uncertainties and in particular it is difficult to forecast energy production which is based upon many variables. Considering Japan's nuclear power FY 2030 target, empirical developments in recent years have substantially reduced uncertainties not to the extent that it is now possible to accurately estimate the volume that will be generated from nuclear power in that year, but sufficiently to assert that the target in question is likely to be missed unless 
unexpected changes, which are discussed in Section 4, take place. Unless otherwise noted, all information referred to in this section comes from Japan Atomic Industrial Forum's Current Status of Nuclear Power Plants in Japan (as of July 6, 2021) [2].

In Japan as of July 2021, there were 33 existing reactors and 2 reactors under constructions (according to the definition of the International Atomic Energy Agency [24], which does not count Tokyo Electric Power Company (TEPCO)'s Higashidori-1 project as under construction because it is only at the geological survey stage, i.e., the first major placing of concrete for the base mat of the reactor building has not been made).

Regarding the 33 existing reactors, 9 had restarted commercial operation, 7 had received the official approval by Japan's Nuclear Regulation Authority (NRA) to restart, 9 had applied to receive the approval of the NRA - the review on conformity to the new regulatory requirements is ongoing, and 8 had not submitted such application. Additionally, the 2 reactors under construction (Ohma and Shimane-3) had applied to receive the approval of the NRA.

Table 1 provides all the relevant information for each reactor in order to most accurately project electricity generation from nuclear power in FY 2030. These include their current status, commercial operation starts date, operational lifetime, and gross electrical capacity in megawatt (MW).

To project the amount of electricity to be generated from nuclear power in Japan in FY 2030, four scenarios are developed: Restarted reactors (RR), approval received (AR) (including RR and the reactors having received the NRA's approval, but not having restarted yet), application submitted (AS) (including AR, as well as the reactors having submitted their application to the NRA, but not received its approval yet, among which the two reactors under construction), and all reactors (All R) (including AS and the reactors which have not submitted their application to the NRA yet).

Based on this categorization, Table 2 presents a reorganized list of reactors and their relevant information in each scenario considered. As of July 2021, nuclear power gross electrical capacity in Japan in the different scenarios proposed are: 9,130 MW in RR, 16,245 MW in AR, 27,594 MW in AS, and 35,839 MW in All R. For each scenario projection variations in terms of operational lifetime and of fleet wide annual average capacity factor are tested.

Though most reactors have not received a 60 -year operating license for the time being (only four reactors have been granted a 60-year operating license: Mihama-3, Takahama-1 \& -2 , and Tokai-2), this hypothesis is tested for sensitivity analysis purpose, recognizing, however, that in the current situation this development seems unlikely. Regarding capacity factors: $70 \%$, $85 \%$, and $95 \%$ are the tested hypotheses. Based on data from the Japan Nuclear Energy Safety Organization [25], a capacity factor of 70\% is consistent with those observed in Japan in the years prior to Fukushima accident. A capacity factor of $85 \%$ is high considering the historical maximum of $84 \%$ reached in Japan in FY 1998 [26]. A capacity factor of $95 \%$ is very high, but feasible as empirically demonstrated by the United States in 2019 for example [27]. A capacity factor of 100\% is impossible because of required periods of maintenance on a fleet of nuclear reactors. Table 3 summarizes all the scenarios and sensitivity analyses in this research, and the results are presented in Section 4.

\section{ESTIMATION RESUlTS}

The first step to estimate the future quantity of electricity generated from nuclear power in Japan in FY 2030 consists in projecting future operational gross electrical capacity of nuclear power at this date. This is done by verifying the status of each nuclear reactor (i.e., operational or permanently shut down) at the end of FY 2030 assuming the two previously proposed operational lifetime 
Journal of Asian Energy Studies (2021), Vol. 5, 22-41

Table 1: Current status of nuclear reactors in Japan, as of July 2021

\begin{tabular}{|c|c|c|c|c|}
\hline Current status & Reactor & $\begin{array}{l}\text { Commercial opera- } \\
\text { tion start date }\end{array}$ & $\begin{array}{l}\text { Operational } \\
\text { lifetime } \\
\text { (year) }\end{array}$ & $\begin{array}{l}\text { Gross electricity } \\
\text { capacity (MW) }\end{array}$ \\
\hline \multicolumn{5}{|c|}{ Existing } \\
\hline \multirow{9}{*}{$\begin{array}{l}\text { Restarted } \\
\text { commercial } \\
\text { operation (1) }\end{array}$} & Genkai-3 & March 18, 1994 & 40 & 1,180 \\
\hline & Genkai-4 & July 25, 1997 & 40 & 1,180 \\
\hline & Ikata-3 & December 15, 1994 & 40 & 890 \\
\hline & Ohi-3 & December 18, 1991 & 40 & 1,180 \\
\hline & Ohi-4 & February 2, 1993 & 40 & 1,180 \\
\hline & Sendai-1 & July 4, 1984 & 40 & 890 \\
\hline & Sendai-2 & November 28, 1985 & 40 & 890 \\
\hline & Takahama-3 & January 17, 1985 & 40 & 870 \\
\hline & Takahama-4 & June 5, 1985 & 40 & 870 \\
\hline Sub-total (1) & 9 reactors & $\mathrm{N} / \mathrm{A}$ & $\mathrm{N} / \mathrm{A}$ & 9,130 \\
\hline \multirow{7}{*}{$\begin{array}{l}\text { NRA's } \\
\text { official } \\
\text { approval } \\
\text { received (2) }\end{array}$} & $\begin{array}{l}\text { Kashiwazaki } \\
\text { Kariwa-6 }\end{array}$ & November 7, 1996 & 40 & 1,356 \\
\hline & $\begin{array}{l}\text { Kashiwazaki } \\
\text { Kariwa-7 }\end{array}$ & July 2, 1997 & 40 & 1,356 \\
\hline & Mihama-3 & December 1, 1976 & 60 & 826 \\
\hline & Onagawa-2 & July 28, 1995 & 40 & 825 \\
\hline & Takahama-1 & November 14, 1974 & 60 & 826 \\
\hline & Takahama-2 & November 14, 1975 & 60 & 826 \\
\hline & Tokai-2 & November 28, 1978 & 60 & 1,100 \\
\hline Sub-total (2) & 7 reactors & $\mathrm{N} / \mathrm{A}$ & $\mathrm{N} / \mathrm{A}$ & 7,115 \\
\hline \multirow{9}{*}{$\begin{array}{l}\text { Application } \\
\text { submitted to } \\
\text { NRA (3) }\end{array}$} & Hamaoka-3 & August 28, 1987 & 40 & 1,100 \\
\hline & Hamaoka-4 & September 3, 1993 & 40 & 1,137 \\
\hline & Higashidori-1 & December 8, 2005 & 40 & 1,100 \\
\hline & Shika-2 & March 15, 2006 & 40 & 1,206 \\
\hline & Shimane-2 & February 10, 1989 & 40 & 820 \\
\hline & Tomari-1 & June 22, 1989 & 40 & 579 \\
\hline & Tomari-2 & April 12, 1991 & 40 & 579 \\
\hline & Tomari-3 & December 22, 2009 & 40 & 912 \\
\hline & Tsuruga-2 & February 17, 1987 & 40 & 1,160 \\
\hline Sub-total (3) & 9 reactors & $\mathrm{N} / \mathrm{A}$ & $\mathrm{N} / \mathrm{A}$ & 8,593 \\
\hline
\end{tabular}

hypotheses (current planned lifetime and 60-year lifetime only), and by aggregating the gross electrical capacity of operational reactors in each scenario considered (RR/AR/AS/All R). Table 4 provides detailed information on the projected status and operational gross electrical capacity of nuclear reactors in Japan at the end of FY 2030 depending on operational lifetime hypotheses retained and for each scenario.

On the one hand, under the hypothesis of current planned lifetime, nuclear power gross electrical capacity in Japan at the end of FY 2030 reaches: 5,610 MW in RR, 12,725 MW in AR, 20,415 MW in AS, and 25,360 MW in All R. In all scenarios, this is less gross electrical capacity than in the current situation (as of July 2021, see Table 2): A decrease of 3,520-10,479 MW (depending on the scenarios). These reductions are due to the permanent shutdowns of 4-11 nuclear reactors 
Journal of Asian Energy Studies (2021), Vol. 5, 22-41

Table 1 (cont.): Current status of nuclear reactors in Japan, as of July 2021

\begin{tabular}{|c|c|c|c|c|}
\hline Current status & Reactor & $\begin{array}{l}\text { Commercial operation } \\
\text { start date }\end{array}$ & $\begin{array}{l}\text { Operational } \\
\text { lifetime } \\
\text { (year) }\end{array}$ & $\begin{array}{l}\text { Gross electricity ca- } \\
\text { pacity (MW) }\end{array}$ \\
\hline \multirow{10}{*}{$\begin{array}{l}\text { No } \\
\text { application } \\
\text { submitted to } \\
\text { NRA (4) }\end{array}$} & Hamaoka-5 & January 18, 2005 & 40 & 1,380 \\
\hline & Kashiwazaki & September 18, 1985 & 40 & 1,100 \\
\hline & Kariwa-1 & \multirow{3}{*}{ September 28, 1990} & \multirow{3}{*}{40} & \multirow{3}{*}{1,100} \\
\hline & Kashiwazaki & & & \\
\hline & Kariwa-2 & & & \\
\hline & Kashiwazaki & \multirow[t]{2}{*}{ August 11, 1993} & \multirow[t]{2}{*}{40} & \multirow[t]{2}{*}{1,100} \\
\hline & Kariwa-3 & & & \\
\hline & $\begin{array}{l}\text { Kashiwazaki } \\
\text { Kariwa-4 }\end{array}$ & August 11, 1994 & 40 & 1,100 \\
\hline & $\begin{array}{l}\text { Kashiwazaki } \\
\text { Kariwa-5 }\end{array}$ & April 10, 1990 & 40 & 1,100 \\
\hline & Onagawa-3 & January 30, 2002 & 40 & 825 \\
\hline \multirow[b]{2}{*}{ Sub-total (4) } & Shika-1 & July 30, 1993 & 40 & 540 \\
\hline & 8 reactors & Not applicable & $\begin{array}{l}\text { Not applica- } \\
\text { ble }\end{array}$ & 8,245 \\
\hline \multicolumn{5}{|l|}{$(1)+(2)+(3)+(4)$} \\
\hline \multicolumn{5}{|c|}{ Under construction } \\
\hline \multirow{2}{*}{$\begin{array}{l}\text { Application } \\
\text { submitted } \\
\text { NRA }\end{array}$} & Ohma & FY 2025 & 40 & \multirow{2}{*}{$\begin{array}{l}1,383 \\
1,373\end{array}$} \\
\hline & Shimane-3 & FY 2021 & 40 & \\
\hline Total & 2 reactors & $\mathrm{N} / \mathrm{A}$ & $\mathrm{N} / \mathrm{A}$ & 2,756 \\
\hline
\end{tabular}

Note: The permanent shutdown of a reactor takes place at the end of its operational lifetime which starts to be counted from the commercial operation start date.

(again depending on scenarios) which will have reached the end of their current planned operating lifetime at the end of FY 2030 (as for examples Sendai-1 \& -2 or Hamaoka-3).

On the other hand, setting a 60-year operational lifetime to all reactors in Japan results in no permanent reactor shutdown in the period studied, i.e., a situation similar to that as of July 2021. Thus, under the hypothesis of 60-year lifetime only, nuclear power gross electrical capacity in Japan at the end of FY 2030 remains at: 9,130 MW in RR, 16,245 MW in AR, 27,594 MW in AS, and 35,839 MW in All R.

The next step consists in estimating the volume of electricity to be generated from nuclear power in FY 2030, considering all the different scenarios, the two operational lifetime hypotheses, and for each of the three levels of capacity factors retained: $70 \%, 85 \%$, and $95 \%$, and then compare these projections with the targeted range of 216.8 and 231.7 TWh.

The formula applied to project electricity generation from Japan's nuclear reactors in FY 2030 is: Nuclear power projected gross electrical capacity in FY 2030, depending on scenarios (RR / AR / AS / All R) and assumed operational lifetime (current planned lifetime / 60-year lifetime only) (see Table 4$) \times$ capacity factors assumed $(70 \%$ / 85\% / 95\%) $\times$ number of hours in FY 2030 (8,760 hours). For example, in the least favorable case; RR, current planned lifetime, and a capacity factor of $70 \%$ the application of the formula aforementioned results in: 5,610 (MW) $\times 70 \% \times 8,760$ (hours) $=34,400,520$ megawatt-hours $(\mathrm{MWh})$ or about $34.4 \mathrm{TWh}$. Fig. 2 shows nuclear electricity 
Journal of Asian Energy Studies (2021), Vol. 5, 22-41

Table 2: List of reactors in each scenario and their relevant information, as of July 2021

\begin{tabular}{|c|c|c|c|c|}
\hline Scenario & Reactor & $\begin{array}{l}\text { Commercial opera- } \\
\text { tion start date }\end{array}$ & $\begin{array}{l}\text { Operational } \\
\text { lifetime } \\
\text { (year) }\end{array}$ & $\begin{array}{l}\text { Gross electricity } \\
\text { capacity (MW) }\end{array}$ \\
\hline \multirow{9}{*}{ RR } & Genkai-3 & March 18, 1994 & 40 & 1,180 \\
\hline & Genkai-4 & July 25, 1997 & 40 & 1,180 \\
\hline & Ikata-3 & December 15, 1994 & 40 & 890 \\
\hline & Ohi-3 & December 18, 1991 & 40 & 1,180 \\
\hline & Ohi-4 & February 2, 1993 & 40 & 1,180 \\
\hline & Sendai-1 & July 4,1984 & 40 & 890 \\
\hline & Sendai-2 & November 28, 1985 & 40 & 890 \\
\hline & Takahama-3 & January 17, 1985 & 40 & 870 \\
\hline & Takahama-4 & June 5, 1985 & 40 & 870 \\
\hline Total RR & 9 reactors & $\mathrm{N} / \mathrm{A}$ & $\mathrm{N} / \mathrm{A}$ & 9,130 \\
\hline $\begin{array}{l}\text { AR } \\
\text { (including }\end{array}$ & $\begin{array}{l}\text { Kashiwazaki } \\
\text { Kariwa-6 }\end{array}$ & November 7, 1996 & 40 & 1,356 \\
\hline $\begin{array}{l}\mathrm{RR} \text { and the } \\
\text { reactors }\end{array}$ & $\begin{array}{l}\text { Kashiwazaki } \\
\text { Kariwa-7 }\end{array}$ & July 2, 1997 & 40 & 1,356 \\
\hline having & Mihama-3 & December 1, 1976 & 60 & 826 \\
\hline received & Onagawa-2 & July 28, 1995 & 40 & 825 \\
\hline NRA's & Takahama-1 & November 14, 1974 & 60 & 826 \\
\hline \multirow[t]{2}{*}{ approval) } & Takahama-2 & November 14, 1975 & 60 & 826 \\
\hline & Tokai-2 & November 28, 1978 & 60 & 1,100 \\
\hline Total AR & 16 reactors & $\mathrm{N} / \mathrm{A}$ & $\mathrm{N} / \mathrm{A}$ & 16,245 \\
\hline AS & Hamaoka-3 & August 28, 1987 & 40 & 1,100 \\
\hline (including & Hamaoka-4 & September 3, 1993 & 40 & 1,137 \\
\hline $\mathrm{AR}$ and the & Higashidori-1 & December 8, 2005 & 40 & 1,100 \\
\hline reactors & Ohma & FY 2025 & 40 & 1,383 \\
\hline having & Shika-2 & March 15, 2006 & 40 & 1,206 \\
\hline submitted & Shimane-2 & February 10, 1989 & 40 & 820 \\
\hline their & Shimane-3 & FY 2021 & 40 & 1,373 \\
\hline application & Tomari-1 & June 22, 1989 & 40 & 579 \\
\hline \multirow[t]{3}{*}{ to the NRA) } & Tomari-2 & April 12, 1991 & 40 & 579 \\
\hline & Tomari-3 & December 22, 2009 & 40 & 912 \\
\hline & Tsuruga-2 & February 17, 1987 & 40 & 1,160 \\
\hline Total AS & 27 reactors & $\mathrm{N} / \mathrm{A}$ & $\mathrm{N} / \mathrm{A}$ & 27,594 \\
\hline
\end{tabular}

generation FY 2030 projections in all explored scenarios under all hypotheses retained (vertical bars), as well as the official targeted range (horizontal bar).

First of all, this exercise demonstrates that under current planned lifetime, the targeted range will not be achieved under all explored scenarios and assumptions. More precisely, the bottom of the targeted range will be missed by 182.4 TWh or $84 \%$ in a worst-case scenario (RR and capacity factor of $70 \%$ ) and by 1.0 TWh or a mere $0.4 \%$ in a best-case scenario (All R and 95\% capacity factor).

Second, it shows that if all reactors are granted 60-year operating licenses by the NRA and that they are operated until the end of this time limit, the targeted range may be achieved in four 
Journal of Asian Energy Studies (2021), Vol. 5, 22-41

Table 2 (cont.): List of reactors in each scenario and their relevant information, as of July 2021

\begin{tabular}{|c|c|c|c|c|}
\hline Current status & Reactor & $\begin{array}{l}\text { Commercial operation } \\
\text { start date }\end{array}$ & $\begin{array}{l}\text { Operational } \\
\text { lifetime } \\
\text { (year) }\end{array}$ & $\begin{array}{l}\text { Gross electricity ca- } \\
\text { pacity (MW) }\end{array}$ \\
\hline All R & Hamaoka-5 & January 18, 2005 & 40 & 1,380 \\
\hline (including & Kashiwazaki & September 18, 1985 & 40 & 1,100 \\
\hline AS and the & Kariwa-1 & & & \\
\hline $\begin{array}{l}\text { reactors } \\
\text { which have }\end{array}$ & $\begin{array}{l}\text { Kashiwazaki } \\
\text { Kariwa-2 }\end{array}$ & September 28, 1990 & 40 & 1,100 \\
\hline & Kashiwazaki & August 11, 1993 & 40 & 1,100 \\
\hline submitted & Kariwa-3 & & & \\
\hline $\begin{array}{l}\text { their } \\
\text { application }\end{array}$ & $\begin{array}{l}\text { Kashiwazaki } \\
\text { Kariwa-4 }\end{array}$ & August 11, 1994 & 40 & 1,100 \\
\hline \multirow[t]{3}{*}{ to the NRA) } & $\begin{array}{l}\text { Kashiwazaki } \\
\text { Kariwa-5 }\end{array}$ & April 10, 1990 & 40 & 1,100 \\
\hline & Onagawa-3 & January 30, 2002 & 40 & 825 \\
\hline & Shika-1 & July 30, 1993 & 40 & 540 \\
\hline Total All R & 35 reactors & N/A & $\mathrm{N} / \mathrm{A}$ & 35,839 \\
\hline
\end{tabular}

Table 3: Reasonable scenario settings and assumptions including extreme case

\begin{tabular}{lll}
\hline Scenario & Operational lifetime hypotheses & Capacity factor \\
\hline RR & Current planned lifetime (40 or 60 years) / 60-year lifetime only & $70 / 85 / 95$ \\
AR & Current planned lifetime (40 or 60 years) / 60-year lifetime only & $70 / 85 / 95$ \\
AS & Current planned lifetime (40 or 60 years) / 60-year lifetime only & $70 / 85 / 95$ \\
All R & Current planned lifetime (40 or 60 years) / 60-year lifetime only & $70 / 85 / 95$ \\
\hline
\end{tabular}

cases. One, in the AS scenario with nuclear reactors operated at $95 \%$ capacity factor. And three in the All R scenario at all capacity factor levels assumed (70\%, 85\%, and $95 \%)$. This highlights the significant potential impact massive lifetime extensions could have. In other cases, the targeted range is to be missed; by at least $11.3 \mathrm{TWh}$, or $5 \%$.

At this point in time, it appears, however, reasonable to reject the most favorable assumptions under which Japan's nuclear power FY 2030 target could be reached. The following paragraphs explains the most important reasons why some of the identified requirements are too extreme to be really credible.

To start with, it is unlikely that all existing reactors will effectively be restarted. As of July 2021, 16 reactors had received the official approval by the NRA to restart commercial operation. Only nine reactors had effectively resumed operation. Mihama-3 and Takahama-1, for which work on safety measures has been completed, may be the next to come back online. They may then be followed by Onagawa-2 and Tokai-2 for which work on safety measures is now expected to be completed in FY 2022. The ending date of work on safety measures for Takahama-2 is undecided. There is a lot more uncertainty for Kashiwazaki Kariwa- 6 \& -7 following the issuance by the NRA of a corrective action order addressed to TEPCO, preventing it from transporting new uranium fuel to the plant or loading fuel rods into its reactors because of the company's safety breaches including failure to protect nuclear materials [28]. There is no time limit for a corrective action order for the protection of nuclear materials.

The future of the eight reactors having not even applied for the NRA's review on conformity 
Table 4: Projections of nuclear reactors status and operational gross electrical capacity in Japan at the end of FY 2030

\begin{tabular}{|c|c|c|c|c|c|}
\hline \multirow[t]{2}{*}{ Scenario } & \multirow[t]{2}{*}{ Reactor } & \multicolumn{2}{|c|}{$\begin{array}{l}\text { FY } 2030 \text { - Current planned } \\
\text { lifetime hypothesis }\end{array}$} & \multicolumn{2}{|c|}{$\begin{array}{l}\text { FY } 2030 \text { - } 60 \text {-year lifetime } \\
\text { only hypothesis }\end{array}$} \\
\hline & & Status & $\begin{array}{l}\text { Operational } \\
\text { gross } \\
\text { electrical } \\
\text { capacity } \\
\text { (MW) }\end{array}$ & Status & $\begin{array}{l}\text { Operational } \\
\text { gross } \\
\text { electrical } \\
\text { capacity } \\
\text { (MW) }\end{array}$ \\
\hline \multirow{9}{*}{$\mathrm{RR}$} & Genkai-3 & $\mathrm{O}$ & 1,180 & $\mathrm{O}$ & 1,180 \\
\hline & Genkai-4 & $\mathrm{O}$ & 1,180 & $\mathrm{O}$ & 1,180 \\
\hline & Ikata-3 & $\mathrm{O}$ & 890 & $\mathrm{O}$ & 890 \\
\hline & Ohi-3 & $\mathrm{O}$ & 1,180 & $\mathrm{O}$ & 1,180 \\
\hline & Ohi-4 & $\mathrm{O}$ & 1,180 & $\mathrm{O}$ & 1,180 \\
\hline & Sendai-1 & $x$ & - & $\mathrm{O}$ & 890 \\
\hline & Sendai-2 & $X$ & - & $\mathrm{O}$ & 890 \\
\hline & Takahama-3 & $X$ & - & $\mathrm{O}$ & 870 \\
\hline & Takahama-4 & X & - & $\mathrm{O}$ & 870 \\
\hline Total RR & & 5 reactors & 5,610 & 9 reactors & 9,130 \\
\hline $\begin{array}{l}\text { AR } \\
\text { (including }\end{array}$ & $\begin{array}{l}\text { Kashiwazaki } \\
\text { Kariwa-6 }\end{array}$ & $\mathrm{O}$ & 1,356 & $\mathrm{O}$ & 1,356 \\
\hline $\begin{array}{l}\mathrm{RR} \text { and the } \\
\text { reactors }\end{array}$ & $\begin{array}{l}\text { Kashiwazaki } \\
\text { Kariwa-7 }\end{array}$ & $\mathrm{O}$ & 1,356 & $\mathrm{O}$ & 1,356 \\
\hline having & Mihama-3 & $\mathrm{O}$ & 826 & $\mathrm{O}$ & 826 \\
\hline received & Onagawa-2 & $\mathrm{O}$ & 825 & $\mathrm{O}$ & 825 \\
\hline NRA's & Takahama-1 & $\mathrm{O}$ & 826 & $\mathrm{O}$ & 826 \\
\hline \multirow[t]{2}{*}{ approval) } & Takahama-2 & $\mathrm{O}$ & 826 & $\mathrm{O}$ & 826 \\
\hline & Tokai-2 & $\mathrm{O}$ & 1,100 & $\mathrm{O}$ & 1,100 \\
\hline \multirow[t]{2}{*}{ Total AR } & & 12 reactors & 12,725 & 16 reactors & 16,245 \\
\hline & Hamaoka-3 & $X$ & - & $\mathrm{O}$ & 1,100 \\
\hline AS & Hamaoka-4 & $\mathrm{O}$ & 1,137 & $\mathrm{O}$ & 1,137 \\
\hline (including & Higashidori-1 & $\mathrm{O}$ & 1,100 & $\mathrm{O}$ & 1,100 \\
\hline $\mathrm{AR}$ and the & Ohma & $\mathrm{O}$ & 1,383 & $\mathrm{O}$ & 1,383 \\
\hline reactors & Shika-2 & $\mathrm{O}$ & 1,206 & $\mathrm{O}$ & 1,206 \\
\hline having & Shimane-2 & $X$ & - & $\mathrm{O}$ & 820 \\
\hline submitted & Shimane-3 & $\mathrm{O}$ & $1,373 \mathrm{O}$ & 1,373 & \\
\hline their & Tomari-1 & $X$ & - & $\mathrm{O}$ & 579 \\
\hline application & Tomari-2 & $\mathrm{O}$ & 579 & $\mathrm{O}$ & 579 \\
\hline \multirow[t]{2}{*}{ to the NRA) } & Tomari-3 & $\mathrm{O}$ & 912 & $\mathrm{O}$ & 912 \\
\hline & Tsuruga-2 & $\mathrm{X}$ & - & $\mathrm{O}$ & 1,160 \\
\hline Total AS & & 19 reactors & 20,415 & 27 reactors & 27,594 \\
\hline
\end{tabular}

to the new regulatory requirements is even more uncertain. Especially for the five reactors Kashiwazaki Kariwa-1 to -5 capable of generating 33.7-45.8 TWh annually (aggregated gross electrical capacity of 5,500 MW $\times$ range of capacity factors of 70\%-95\% $\times 8,760$ hours in FY 2030). Kashiwazaki mayor, Masahiro Sakurai, insists that TEPCO compile a plan about the decommissioning of these five reactors as a condition of his consent to the restarts of Kashiwazaki Kariwa-6 \& -7 [29]. 
Table 4 (cont.): Projections of nuclear reactors status and operational gross electrical capacity in Japan at the end of FY 2030

\begin{tabular}{|c|c|c|c|c|c|}
\hline \multirow[t]{2}{*}{ Scenario } & \multirow[t]{2}{*}{ Reactor } & \multicolumn{2}{|c|}{$\begin{array}{l}\text { FY } 2030 \text { - Current planned life- } \\
\text { time hypothesis }\end{array}$} & \multicolumn{2}{|c|}{$\begin{array}{l}\text { FY } 2030 \text { - 60-year lifetime only } \\
\text { hypothesis }\end{array}$} \\
\hline & & Status & $\begin{array}{l}\text { Operational } \\
\text { gross elec- } \\
\text { trical } \\
\text { capacity } \\
\text { (MW) }\end{array}$ & Status & $\begin{array}{l}\text { Operational } \\
\text { gross elec- } \\
\text { trical } \\
\text { capacity } \\
\text { (MW) }\end{array}$ \\
\hline All R & Hamaoka-5 & $\mathrm{O}$ & 1,380 & $\mathrm{O}$ & 1,380 \\
\hline (including & Kashiwazaki & $x$ & - & $\mathrm{O}$ & 1,100 \\
\hline AS and the & Kariwa-1 & & & & \\
\hline reactors & Kashiwazaki & $X$ & - & $\mathrm{O}$ & 1,100 \\
\hline which have & Kariwa-2 & & & & \\
\hline $\begin{array}{l}\text { not } \\
\text { submitted }\end{array}$ & $\begin{array}{l}\text { Kashiwazaki } \\
\text { Kariwa-3 }\end{array}$ & $\mathrm{O}$ & 1,100 & $\mathrm{O}$ & 1,100 \\
\hline their & $\begin{array}{l}\text { Kashiwazaki } \\
\text { Kariwa-4 }\end{array}$ & $\mathrm{O}$ & 1,100 & $\mathrm{O}$ & 1,100 \\
\hline to the NRA) & $\begin{array}{l}\text { Kashiwazaki } \\
\text { Kariwa-5 }\end{array}$ & $X$ & - & $\mathrm{O}$ & 1,100 \\
\hline & Onagawa-3 & $\mathrm{O}$ & 825 & $\mathrm{O}$ & 825 \\
\hline & Shika-1 & $\mathrm{O}$ & 540 & $\mathrm{O}$ & 540 \\
\hline Total All R & & 24 reactors & 25,360 & 35 reactors & 35,839 \\
\hline
\end{tabular}

Note: " $\mathrm{O}$ " indicates an operational nuclear reactor, and " $\mathrm{X}$ " a permanently shut down nuclear reactor.

So far, TEPCO only proposed to decommission one or more reactors. Considering the considerable amount of electricity that could be generated from Kashiwazaki Kariwa-1 to -5 , the decision that will be made on the future operations of these reactors will heavily weigh on Japan's meeting or not its nuclear power FY 2030 target.

Regarding lifetime extensions of reactors to 60 years, experience (the four reactor examples previously mentioned) has shown that Japan's NRA may grant such authorizations. Nevertheless, this fact may also be counterbalanced by another convincing evidence: Since FY 2015 four times more reactors (16) have been permanently shut down because Japanese power companies came to the conclusion that required investments to meet more stringent safety standards and pursue lifetime extensions were prohibitively expensive and/or too challenging technically. In this framework, Kansai Electric Power Company for example announced in FY 2017 the closures of reactors Ohi-1 \& -2 [30]. More similar announcements could still be coming, especially from some of the five reactors which have only five years or less left on their operating licenses (Kashiwazaki Kariwa-1, Sendai-1 \& -2, and Takahama-3 \& -4). In contrast, Tokai-2 is a concrete example of a reactor having received the authorization to operate for 60 years. Necessary estimated investments to restart and operate this reactor until the end of its new planned lifetime, however, indicate poor economic prospects [31]. It is therefore not a foregone conclusion that a massive wave of reactor lifetime extensions will be observed in the coming years.

As for capacity factors, though high level of almost $85 \%$ have already been achieved in Japan and can therefore not be completely ruled out, the current mainstream thinking within METI is rather to consider levels of $70 \%$ or $80 \%$ [32]. Capacity factor of $95 \%$ is probably an excessively optimistic assumption that, however, has the merit to emphasize the tremendous challenge to 


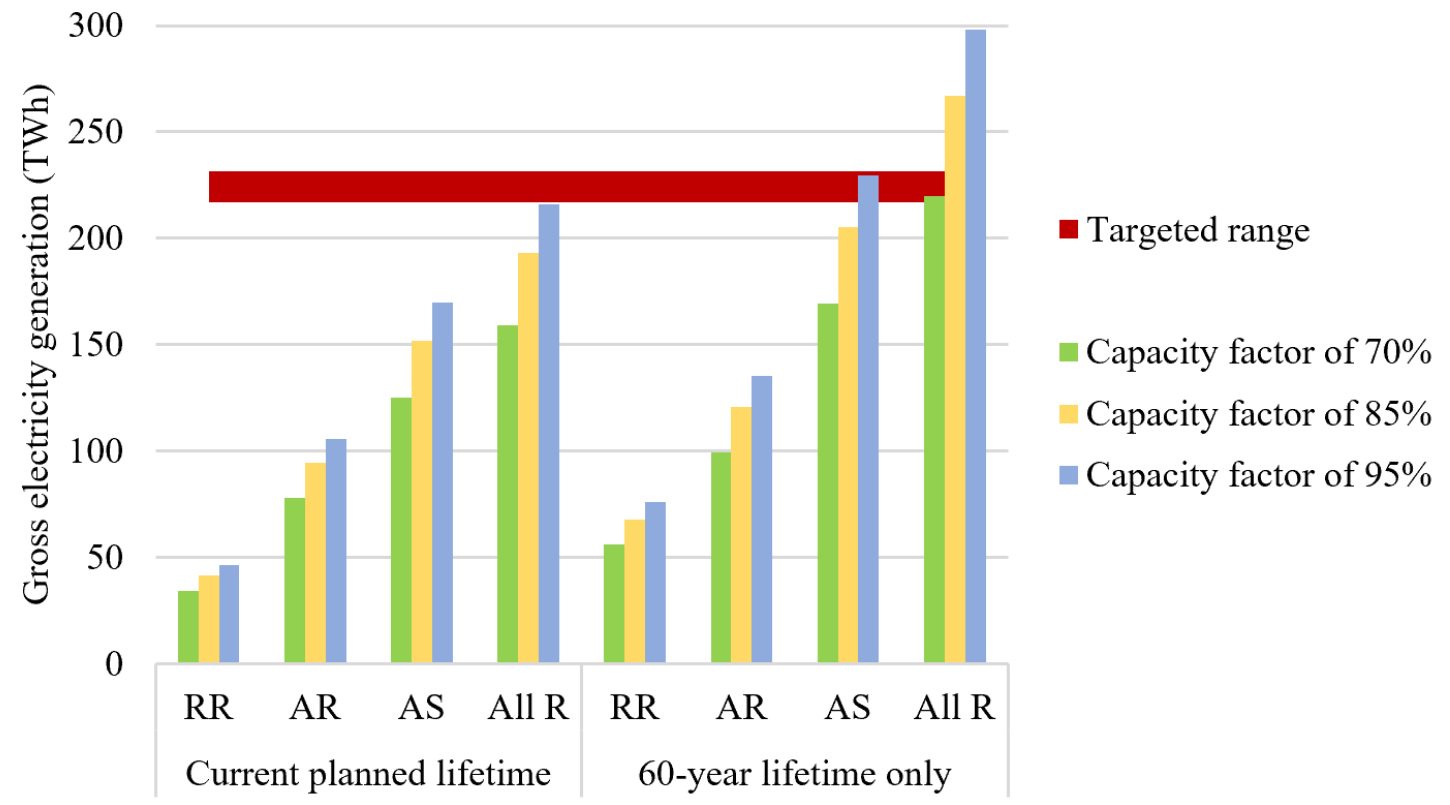

Note: In the "Current planned lifetime" "All R" scenario, the reactors Kashiwazaki Kariwa-2 \& -5 are closed during FY 2030. The electricity generated from these reactors is estimated on a prorated basis of their operating time during FY 2030.

Figure 2: Projections of gross electricity generation from nuclear power in Japan in FY 2030 under various assumptions, and comparison with official national target [2,3]

meet Japan's nuclear power FY 2030 target.

Finally, the last - unexplored in this study - option to increase electricity generation from nuclear power in Japan by FY 2030 would be to build new nuclear reactors, other than the two already under construction. The most likely candidate today would be TEPCO's Higashidori-1 reactor project. Following Fukushima accident, it is nevertheless difficult to promote the idea of new nuclear reactors in Japan based on current available technologies which are socially unpopular [33]. Furthermore, because of limited developments more advanced nuclear technologies such as fast breeder or fusion reactors are quite unlikely to provide solutions for the coming decade.

The next section proposes five alternative options for nuclear power that would contribute to Japan's climate change mitigation action and strengthen the country's security of supply, with a particular focus on international electrical interconnections.

\section{Further CONSIDERATions}

Realistically, since Japan's nuclear power FY 2030 target will likely be missed, and probably by a wide margin, it is critical to consider alternatives to fill in the gap that will be left by insufficient electricity generation from nuclear as well as how can policies be crafted to more closely match actual electrical output.

Before considering these alternatives, it may be suggested that Japan's energy policy should be reviewed more frequently, projections strengthened, and more reactivity and flexibility demon- 
strated by policymakers. Between the last two national energy plans the Long-term Energy Supply and Demand Outlook [3] in 2015 and Strategic Energy Plan [34] in 2018 three years passed, and no revision is now expected before 2021 at the earliest. In comparison, in the European Union and in the United States, where State-level regulatory frameworks are in place, renewable energy and/or decarbonization actual progresses are tracked on an annual basis and any deviations from the objectives are identified rapidly. Regarding projections, especially for nuclear power, a more pragmatic approach such as that proposed in this research paper should be adopted. Finally, in the Literature review section, the example of India was referred to in order to illustrate how a government can demonstrate reactivity and flexibility in terms of energy policy. Another example could be France, where after recognizing that solar PV expansion was too slow and updated projections insufficient to meet the country's objectives for this technology, the government decided to organize additional dedicated tenders [35].

Considering the alternatives in question now, to replace the projected lack of electricity generation from nuclear power in FY 2030, Japan may decide to focus on one or a combination of two or more of the five following solutions - which all satisfy to the requirements of limiting greenhouse gas emissions (for which Japan has a $46 \%$ reduction target by FY 2030, compared to FY 2013 [36]) and reinforcing the country's security of supply in complementary ways: Additional energy efficiency measures, further renewable energies deployment, development of Japan's first international electrical interconnections, adoption of carbon capture and storage (CCS) technologies for fossil power plants, and penetration of hydrogen; blue (using a CCS system) and/or green (using renewable energy to power the electrolysis of water). Compared to energy efficiency, renewable energies, and submarine cables - that would be necessary for cross-border electricity trade with Japan, the latter two options have not reached widespread commercialization yet because of a lack of economic and/or technological maturity. They are therefore not considered hereinafter due to the short timeframe in question. It is, however, noted that Japan has a 2030 target for 1,000 MW of hydrogen power to generate electricity at the high cost of 17 Japanese yen (JPY) per kilowatt-hour (/kWh) [37].

Energy efficiency and greater introduction of renewable energies are already parts of Japan's Long-term Energy Supply and Demand Outlook. Indeed, METI's projects that in FY 2030 (1) thanks to energy efficiency total gross electricity generation of the country will be lowered by $213 \mathrm{TWh}$ to 1,065 TWh, and (2) electricity generation from renewable energies will reach between 236.6 TWh and $251.5 \mathrm{TWh}$, an objective better known as the $22-24 \%$ target. According to statistics of the IEA as of FY 2019 [38], these two goals were either already reached; total gross electricity generation of $1,000 \mathrm{TWh}$ or in a good way to be reached; electricity generation from renewable electricity equal to 191.8 TWh, about $75-80 \%$ of the FY 2030 target. These very encouraging developments resulting from energy conservation efforts and the introduction of a feed-in tariff scheme [39] may encourage the Japanese government to advance more ambitious targets and support mechanisms in favor of these two solutions. Regarding energy efficiency, policies to spur more effective insulation measures in the manufacturing and building sectors may result in additional energy savings according to the Renewable Energy Institute (REI) [40]. The implementation of such initiatives, however, depends on the availability of funding sources to help covering the upfront costs of these improvements. As for the further deployment of renewable energies in Japan, among key issues is the economics with the costs of technologies such as solar PV and onshore remaining relatively high compared to global standards based on figures of BloombergNEF: Typically, JPY 12-14/kWh as of the second half of 2020 [41].

In the case of international electrical interconnections, this is an innovative option that has not gathered the same level of positive attention than energy efficiency and renewable energies from policy makers in Japan until now. In its 2018 Strategic Energy Plan, the Japanese government 
referred to international electrical interconnections - for the first time in such high-level official public document - in a rather critical manner, declaring for instance that: "A strategy that expands renewable energy by utilizing international connections has many issues in the case of Japan.". No argument was advanced to directly justify this statement. Moreover, benefits from international electrical interconnections in terms of climate change mitigation and security of supply are even largely ignored despite empirical evidences. The following two paragraphs briefly treat of each of these benefits successively relying on examples of France's international electricity trade with neighboring countries.

France is usually a net exporter of electricity with its neighboring countries (e.g., Italy, Spain, the United Kingdom... ). It is, however, a net importer of electricity from Germany because wholesale power prices are lower in Germany than in France, which is due to the higher penetration of close to zero marginal costs solar PV and wind in Germany [42]. As a result, these two low carbon emitting technologies on the other side of the border have contributed to reduce France's domestic electricity generation from higher marginal costs and more polluting coal power, and its declining nuclear output.

Furthermore, in 2016-2017, France was forced to shut down multiple nuclear reactors because of safety concerns due to irregularities in quality-control documentation and manufacturing defects [43]. This led to a major supply shortage. According to data from the French transmission system operator Réseau de Transport d'Électricité, France became a net importer of electricity in January 2017, with a difference between imports and exports of 1.0 TWh [44]. This event demonstrated that international electrical interconnections not only preserve stability of supply in France, but also help rein surging prices.

Beyond climate change mitigation and security of supply, international electrical interconnections may also contribute to improve power systems resiliency issue. Japan is particularly prone to natural disasters, and the experience of the Great East Japan Earthquake that triggered the tsunami and the major accident at the Fukushima Daiichi nuclear power plant has highlighted the need for a power system operated over a wider area [45]. At the national level, this need has been at the core of the electricity market reform in Japan after Fukushima, and it has led to the establishment of the Organization for Cross-regional Coordination of Transmission Operators (OCCTO) at the beginning of the FY 2015 [46]. This organization aims at promoting the development of electricity transmission and distribution networks, which are necessary for cross-regional electricity use, and enhancing the nationwide function of adjusting the supply-demand balance of electricity in both normal and emergency situations. This is a first step towards a power system operated over a wider area. So far, however, OCCTO is only considering the expansion and reinforcement of the domestic electrical grid as demonstrated by the organization's preliminary wide area interconnection system master plan [47]. International electrical interconnections could be a next step.

Focusing into more details on the possibilities of international electrical interconnections in Japan: According to preliminary research referring to real project experiences, Ichimura and Omatsu [48] have found that the development of international electrical interconnections of 2,000 MW of transmission capacity is technically feasible with Russia and South Korea. Based on the aforementioned study, and for reference purposes, Table 5 presents the different possible interconnection routes between Japan and these two countries, including information on the distance between the landing points in the two countries (kilometers), the maximum sea depth to be considered for the submarine cables (meters), and associated estimated costs (JPY billion).

It may be noted that while single landing points are indicated for Russia (Sakhalin, in far east Russia) and South Korea (Busan, in southeast South Korea), several are assessed for Japan because of practical considerations including available transmission capacity, and proximity to demand 
Journal of Asian Energy Studies (2021), Vol. 5, 22-41

Table 5: Information on the possible interconnection routes between Japan and Russia, and Japan and South Korea

\begin{tabular}{lllll}
\hline $\begin{array}{l}\text { Country intercon- } \\
\text { nection }\end{array}$ & Route & $\begin{array}{l}\text { Distance } \\
(\mathrm{km})\end{array}$ & $\begin{array}{l}\text { Maximum } \\
\text { depth }(\mathrm{m})\end{array}$ & $\begin{array}{l}\text { Cost (JPY } \\
\text { bn) }\end{array}$ \\
\hline \multirow{3}{*}{ Russia $\rightarrow$ Japan } & Sakhalin-Kashiwazaki & 1,255 & 300 & 430.5 \\
& Sakhalin-Ishikari & 455 & 300 & 196.1 \\
& Sakhalin-Wakkanai & 161 & $\leq 100$ & 110.0 \\
South & Busan-Maizuru & 627 & 200 & 246.5 \\
Korea $\rightarrow$ Japan & Busan-Matsue & 372 & 150 & 171.8 \\
& Busan-Imari & 226 & 120 & 129.0 \\
\hline
\end{tabular}

centers. Considering four business models, Kimura and Ichimura [49] went one step further by demonstrating that these possible interconnection routes could be economically profitable.

With regard to an interconnection with South Korea specifically, Zissler and Cross [50] by comparing power exchange prices in the two countries, have confirmed the previous economic findings and gone further by analyzing that this international trade could have been particularly beneficial to Japan in the period 2018-2019. In other words, there are business opportunities for Japanese electric power companies to trade electricity with South Korea. This should raise the interest of decision makers in Japan.

Moreover, qualitative analysis by the Asia International Grid Connection Study Group [51] finds that international electrical interconnections would have a positive effect on climate change mitigation and energy security in Japan.

Based on all these observations it is reasonable to advance the idea that Japan could develop two international electrical interconnections, one with Russia and one with South Korea, each with a transmission capacity of 2,000 MW (as described in [48]). It may then be estimated that a maximum of 35.0 TWh could be traded annually between Japan and these two countries. This result comes from the application of the following formula: Number of electrical interconnections (2) $\times$ transmission capacity of each electrical interconnection $(2,000 \mathrm{MW}) \times$ maximum availability and electricity flow for both interconnections $(100 \%) \times$ number of hours in a year $(8,760$ hours); 2 $\times 2,000(\mathrm{MW}) \times 100 \% \times 8,760$ (hours) $=35,040,000 \mathrm{MWh}$ or around $35 \mathrm{TWh}$. Some of this volume could be imported to Japan and contribute to fill in the gap left by the insufficient domestic electricity generation from nuclear power. Regarding the low carbon electricity imported, it could be renewable energies such as hydro from Russia [52], and/or solar and wind from South Korea if the plans of the Ministry of Trade, Industry and Energy are realized [53].

Additionally, international electrical interconnections could facilitate the integration of variable renewable energies in Japan, as for example solar power facing curtailment in Kyushu area (the only area affected by curtailment in Japan until now). Fig. 3 illustrates this acute issue referring to April 18, 2021 when a record 3,719 MW of renewable energy (essentially solar PV) was curtailed in Kyushu at 13:00, power supply exceeding demand in that area. At that time, the domestic interconnection to export power to the Chugoku area was fully utilized so were pumped hydro pumping capacity, and fossil power plants could not lower their output further down. It may be noted that nuclear power output was not adjusted downwards because this technology benefits of priority dispatch over solar PV and wind in Japan.

Thus, had an interconnection existed between Kyushu and South Korea, at least some of this low carbon low marginal cost electricity could have been traded instead of being wasted. The combination of international electrical interconnections and renewable energies could hence be quite relevant in this economic, environmental, and technical framework as well. 


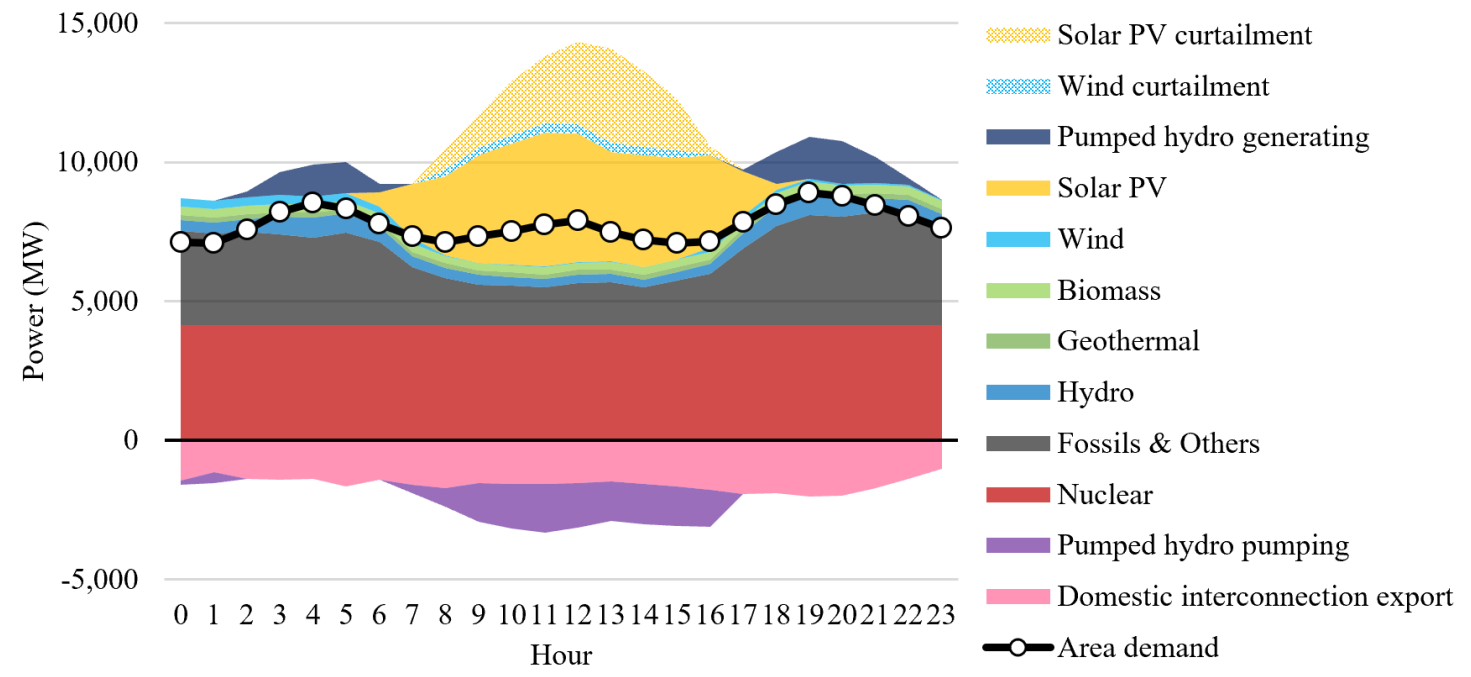

Figure 3: Kyushu hourly power supply and demand on April 18, 2021 [54]

In Japan, there is, however, one main concern with the international electrical interconnection option: Energy security. It is sometimes considered that Japan could be left vulnerable to supply disruptions for political reasons, as for example resource nationalism. Japan's diplomatic relationships with its neighbors are complicated, in particular with Russia with which no peace treaty has been ratified to formally end World War II hostilities. In recent years, relationships with South Korea have also not always been set fair. However, such project by developing mutually dependent ties has the potential to be an ice-breaker to restore good ties between the two countries. In addition, still on a positive note, it may be highlighted that the risks associated with supply disruptions can be mitigated either by limiting the size of the interconnections or by diversifying their origins.

Finally, regarding the timeframe, the decade 2020-2030 is admittedly a challenging short period of time to realize such infrastructure project. However, again, this issue appears to be closely related to political diplomacy rather than to technological deployment. For instance, the Australia-ASEAN Power Link project [55] aims to interconnect Australia and Singapore in less than ten years (2018; foundation of Sun Cable, the company at the helm of the initiative-2027; start of commercial operations), including the start of operation of a more than 3,700 kilometers submarine cable - a far greater distance than there is between Japan and Russia or Japan and South Korea (maximums of 1,255 kilometers and 627 kilometers, respectively, for interconnection routes considered in [48]). If not by 2030, in a little more distant future international electrical interconnections may still be valuable tools for Japan to achieve its newly announced ambitious carbon neutrality objective by 2050, a goal also pursued by South Korea [56].

\section{Conclusions}

Under the current conditions, Japan's nuclear power FY 2030 targeted energy mix will likely be missed. This means a shortage of low carbon electricity and a weakening of the country's security of supply will result. Given curtailment of solar power is already locally taking place in Japan, building additional solar power plants is probably not the only solution to make up for the nuclear power shortfall. Energy efficiency improvements can lessen the impact, however it should be 
noted, international electrical interconnections are credible alternatives to help fill the gap left by Japan's projected failure to meet its nuclear power projections in FY 2030 target and beyond. As a consequence, international electrical interconnections should also be considered part of the equation in Japan to meet its 2030 and 2050 policy plans, security of supply strengthening and resiliency objectives.

Acknowledgement: This paper has benefited from the valuable reviews of Professor Koji Tokimatsu, Tokyo Institute of Technology, and Professor Brian Woodall, Georgia Institute of Technology.

Funding: This research did not receive any specific grant from funding agencies in the public, commercial, or not-for-profit sectors.

\section{REFERENCES}

[1] International Energy Agency. Data and statistics - Nuclear electricity generation, Japan. 2020. https:/ / www.iea.org/data-and-statistics?country=JAPAN\&fuel=Nuclear\&indicator=Nuclear $\% 20$ electricity $\% 20$ generation

[2] Japan Atomic Industrial Forum. Current Status of Nuclear Power Plants in Japan - As of July 6, 2021. Japan Atomic Industrial Forum, Tokyo, 2021.

[3] Ministry of Economy, Trade and Industry. Long-term Energy Supply and Demand Outlook. Ministry of Economy, Trade and Industry, Tokyo, 2015.

[4] Kuriyama A, Tamura K, Kuramochi T. Can Japan enhance its 2030 greenhouse gas emission reduction targets? Assessment of economic and energy-related assumptions in Japan's NDC. Energy Policy 2019:130:328-340.

[5] Yamazaki M, Takeda S. A computable general equilibrium assessment of Japan's nuclear energy policy and implications for renewable energy. Environmental Economics and Policy Studies 2017:19:537-554.

[6] Wakiyama T, Kuriyama A. Assessment of renewable energy expansion potential and its implications on reforming Japan's electricity system. Energy Policy 2018:115:302-316.

[7] Institute of Energy Economics, Japan. Outlook 2020 -Coping with the Increasingly Challenging Energy Trilemma (3Es)-. Institute of Energy Economics, Japan, Tokyo, 2020.

[8] Carrington G, Stephenson J. The politics of energy scenarios: Are International Energy Agency and other conservative projections hampering the renewable energy transition?. Energy Research \& Social Science 2018:46:103-113.

[9] Portugal-Pereira J, Ferreira P, Cunha J, Szklo A, Schaeffer R, Araujo M. Better late than never, but never late is better: Risk assessment of nuclear power construction projects. Energy Policy 2018:120:158-166.

[10] International Energy Agency. World Energy Outlook 2015. International Energy Agency, Paris, 2015.

[11] International Energy Agency. Monthly electricity statistics. 2021. https://www.iea.org/dataand-statistics/data-product/monthly-electricity-statistics

[12] Farmer M. Three key points for power generation from China's five-year plan. 2021. https://www.power-technology.com/news/industry-news/china-five-year-plan-threepoints-nuclear-coal-energy-efficiency /

[13] Fazendeiro L M., Simoes S G.. Historical variation of IEA energy and CO2 emission projections: Implications for future energy modeling. Sustainability 2021:13:7432.

[14] Renewable Energy Institute. The Rise of Renewable Energy and Fall of Nuclear Power: Competition of Low Carbon Technologies. Renewable Energy Institute, Tokyo, 2019. 
[15] Ministry of Economy, Trade and Industry. Curtailment of renewable energy, introducing more renewable energy. 2018. https://www.enecho.meti.go.jp/about/special/johoteikyo/kyushu_syuturyokuseigyo.html

[16] International Energy Agency. European Union 2020 Energy Policy Review. International Energy Agency, Paris, 2020.

[17] European Network of Transmission System Operators for Electricity. Statistical Factsheet 2018. European Network of Transmission System Operators for Electricity, Brussels, 2019.

[18] International Energy Agency. Data and statistics - Electricity, Europe 2018. 2020. https://www.iea.org/data-and-statistics/datatables? country=WEOEUR\&energy=Electricity\&year=2018

[19] International Energy Agency. Establishing Multilateral Power Trade in ASEAN. International Energy Agency, Paris, 2019.

[20] International Energy Agency. Data and statistics - Electricity, ASEAN 2018. 2020. https://www.iea.org/data-and-statistics/datatables? country=MASEAN\&energy=Electricity\&year $=2018$

[21] International Energy Agency. Data and statistics - Electricity, Lao People's Democratic Republic 2018. 2020. https://www.iea.org/data-and-statistics/datatables? country=LAO\&energy=Electricity\&year $=2018$

[22] International Energy Agency. Data and statistics - Electricity, Thailand 2018. 2020. https://www.iea.org/data-and-statistics/datatables? country=THAILAND\&energy=Electricity\&year $=2018$

[23] Prime Minister of Japan and His Cabinet. Policy Speech by the Prime Minister to the 203rd Session of the Diet. 2020. https://www.kantei.go.jp/jp/99_suga/statement/2020/1026shoshinhyomei.html

[24] International Atomic Energy Agency. Power Reactor Information System - Glossary of terms in PRIS reports. 2020. https://pris.iaea.org/PRIS/Glossary.aspx

[25] Japan Nuclear Energy Safety Organization. Operational Status of Nuclear Facilities in Japan 2013 Edition. Japan Nuclear Energy Safety Organization, Tokyo, 2014.

[26] International Atomic Energy Agency. International Nuclear Information System - Overview and Prospects for Nuclear Power Generation in Japan. International Atomic Energy Agency, Vienna, 2000.

[27] International Atomic Energy Agency. Power Reactor Information System - United States of America. 2020. https://pris.iaea.org/PRIS/CountryStatistics/CountryDetails.aspx?current=US

[28] Sheldrick A, Obayashi Y. Japan halts TEPCO plan to restart key nuclear plant after safety breaches. 2021. https://www.reuters.com/business/energy/tepco-punished-safety-breachespreventing-restart-only-operable-nuclear-plant-2021-04-14/

[29] Ishii N. TEPCO to decide fate of Kashiwazaki Kariwa Units 1 to 5 five years after restarting units 6 and 7. 2019. https:/ / www.jaif.or.jp/en/tepco-to-decide-fate-of-kashiwazaki-kariwaunits-1-to-5-five-years-after-restarting-units-6-and-7/

[30] Schneider M. The World Nuclear Industry Status Report 2018. Mycle Schneider Consulting Project, Paris \& London, 2018.

[31] Renewable Energy Institute. Information package - Nuclear Power Decline in Japan. Renewable Energy Institute, Tokyo, 2020.

[32] Ministry of Economy, Trade and Industry - Power Generation Cost Analysis Working Group. Report on Analysis of Generation Costs, Etc. for Subcommittee on Long-term Energy Supply-demand Outlook. Ministry of Economy, Trade and Industry, Tokyo, 2015. 
[33] Okubo T, Narita D, Rehdanz K, Schröder C. Preferences for nuclear power in post-Fukushima Japan: Evidence from a large nationwide household survey. Energies 2020:13:2938.

[34] Ministry of Economy, Trade and Industry. Strategic Energy Plan. Ministry of Economy, Trade and Industry, Tokyo, 2018.

[35] Ministry of the Ecological Transition. Solar. 2021. https://www.ecologie.gouv.fr/solaire

[36] Ministry of Foreign Affairs of Japan. Intended nationally determined contributions (INDC): Greenhouse gas emission reduction target in FY2030. 2021. https://www.mofa.go.jp/ic/ch/page1we_000104.html

[37] Ministry of Economy, Trade and Industry. Basic Hydrogen Strategy. Ministry of Economy, Trade and Industry, Tokyo, 2017.

[38] International Energy Agency. Data and statistics - Electricity, Japan 2019. 2020. https://www.iea.org/data-and-statistics/datatables? country=JAPAN\&energy=Electricity\&year $=2019$

[39] Lo K. Asian energy challenges in the Asian century. Journal of Asian Energy Studies 2017:1:1-6.

[40] Renewable Energy Institute. Proposal for Energy Strategy Toward a Decarbonized Society: Achieving a Carbon-Neutral Japan by 2050. Renewable Energy Institute, Tokyo, 2019.

[41] BloombergNEF. Levelized cost of electricity 2H 2020. 2021. subscription required.

[42] Zissler R. Germany is a net exporter of electricity, even to France. 2018. https://www.renewable-ei.org/en/activities/column/20180302.html

[43] Schneider M. The World Nuclear Industry Status Report 2017. Mycle Schneider Consulting Project, Paris, 2017.

[44] Réseau de Transport d'Électricité. Monthly Electrical Energy Overview January 2017. Réseau de Transport d'Électricité, Paris, 2017.

[45] Goto M, Sueyoshi T. Electricity market reform in Japan after Fukushima. Economics of Energy $\mathcal{E}$ Environmental Policy 2016:5:15-30.

[46] Ministry of Economy, Trade and Industry. Authorization for establishment of the Organization for Cross-regional Coordination of Transmission Operators (OCCTO). 2014. https://www.meti.go.jp/english/press/2014/0822_05.html

[47] Organization for Cross-regional Coordination of Transmission Operators. Intermediate Arrangement Related to Master Plan Examination. Organization for Cross-regional Coordination of Transmission Operators, Tokyo, 2021.

[48] Ichimura S, Omatsu R. Route designs and cost estimation for Japan-Russia and Japan-South Korea interconnections. Global Energy Interconnection 2019:2:133-142.

[49] Kimura S, Ichimura S. Cost-profit analysis for Japan-Russia and Japan-South Korea interconnectors. Global Energy Interconnection 2019:2:114-121.

[50] Zissler R, Cross JS., Impacts of a Japan-South Korea power system interconnection on the competitiveness of electric power companies according to power exchange prices. Global Energy Interconnection 2020:3:292-302.

[51] Asia International Grid Connection Study Group. Third report. Asia International Grid Connection Study Group, Tokyo, 2019.

[52] Asia International Grid Connection Study Group. Interim report. Asia International Grid Connection Study Group, Tokyo, 2017.

[53] Ministry of Trade, Industry and Energy. Ministry announces 8th basic plan for electricity supply and demand. 2017. http://english.motie.go.kr/en/pc/pressreleases/bbs/bbsView.do?bbs _seq_n=605\&bbs_cd_n=2\&currentPage $=1 \&$ search_key_n=\&search_val _v=\&cate_n=

[54] Renewable Energy Institute. Power supply \& demand chart. 2021. https:/ /www.renewableei.org/en/statistics/electricity/\#demand

[55] Sun Cable. Australia-ASEAN Power Link. 2020. https://www.suncable.sg/ 
[56] Jaewon K. South Korea joins Japan in making 2050 carbon-neutral pledge. 2020. https://asia.nikkei.com/Spotlight/Environment/South-Korea-joins-Japan-in-making-2050carbon-neutral-pledge

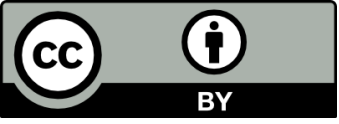

(C) The Author(s) 2021. This article is published under a Creative Commons Attribution (CC-BY) 4.0 International License. 